\section{Javanese Cultural Heritage Building (Case Study: Joglo House)}

\author{
Ghefra Rizkan Gaffara ${ }^{1}$, Dayu Ariesta Kirana Sari ${ }^{2}$, Nanda Saputra ${ }^{3}$ \\ ${ }^{1}$ Faculty of Engineering, Universitas Esa Unggul, Jakarta, Indonesia \\ 2,3STIT Al-Hilal Sigli, Aceh, Indonesia \\ Email: ghefra@esaunggul.ac.id,nandasaputra680@gmail.com
}

\section{Abstract:}

For centuries East Java is one of the tribes in Indonesia that has a unique cultural treasure. This culture has been passed down from generation to generation since the days of the kingdom. Model approach in this research is leading to a descriptive qualitative ethnographic, in which the empirical reality a result, demanding researchers go directly to the location of the study, to be able to live up to their tradition, and the symptoms of everyday life that is full of social phenomena local culture. The relation between construction is a structure which is strongly influenced by the manifestation process mythology and cosmology Java). This means that the traditional Javanese house is not just a place to shelter (practical function), but also understood as a manifestation of the ideals and outlook on life or a symbolic function. In this case the traditional Javanese houses are not only placed as an autonomous element, a separate stand alone, but being seen in context, particularly relevant to the context of allied Javanese cosmology that underlie the view that the Javanese philosophy of life.

Keywords:

Cultural; joglo; model; phenoma; tradition

\section{Introduction}

Physical buildings always mark the level development of human life so that every building is full of intrinsic value about local wisdom. From prehistoric times can be found several artifacts, such as yupa, linga, to paints hands on the walls of caves in Kalimantan able to reconstruct mental life human at that time. When observing the Temple Prampaban then found a statue of Dewi Sri in the courtyard, can be interpreted that the religion adopted society at that time was Hindu. This matter shows that physical buildings which until now is representation of the human life that made it. The spirit of orientalism has brought current to deconstruct the values that have been owned by our nation long before the entry European orientation so that the values of local wisdom is a marker of Javanese civilization has grew from the past. (Triyadi, 2009).

Organization must have a goal to be achieved by the organizational members (Niati et al., 2021). The success of leadership is partly determined by the ability of leaders to develop their organizational culture. (Arif, 2019). The dominant culture or indigenous culture commonly influences the culture of the minority or the immigrant culture, and subsequently, the minority culture is affected by the dominant culture due to the cultural pressures of the culture itself (Pandapotan, 2020).

One of the values of local wisdom was found in a traditional Javanese house. Java has various cultural and artistic beauties integrated into the life of the people. Various traditional arts and culture are contained in Javanese heirloom works, such as batik, joglo house, kris, and gamelan. (Ellen et al, 2005). Joglo actually only a form of traditional Javanese house, but joglo 


\section{Lakhomi Journal: Scientific Journal of Culture \\ ISSN: 2774-311X (Online), 2774-4728 (Print)}

Vol. 2, No. 4, December 2021, Page: 148-153

Email: lakhomijournal@gmail.com

is a the most complete type of Java house so that the value of wisdom contained in This house is also not completely described until now. (Ambrose, James \& Vergum, Dimitry, 1999).

This article reveals the construction of the house Javanese tradition physically and review it from Javanese philosophy. Building or traditional houses are not only built as a place to live, but is also expected to bring happiness and well-being for its residents through the amalgamation of macrocosmic elements and the microcosm in the house. Thus, it is expected that the balance life is achieved and has a positive impact on the occupants. Exploring the philosophical elements in house of Javanese tradition opens up business possibilities the younger generation as heirs of culture in future to maintain and preserve the legacy of its predecessors (Pourdeyhimi, 2010).

\section{Research Method}

The approach model in this research is descriptive qualitative that leads to ethnography, namely in describing a empirical reality of research results, researchers are required togo directly to the research location in order to be able to appreciate the customs and symptoms of daily life which is full of local socio-cultural phenomena. This approach strategy was chosen on the basis of the consideration that (1) the qualitative approach even though it only covers a small/limited scale of research locations, is able to develop in a broader conceptual framework, (2) this approach model is not only concerned with results, but the process aspect is something more important, even (3) This ethnographic qualitative approach is very good if a study wants to explain a phenomenon in depth and comprehensively so that the results of the research are: detailed descriptions that are not rigid but also in-depth.

\section{Result and Discussion}

\subsection{Joglo and Its Unique Concept}

The historical development of joglo cannot be separated from an ancient building called punden terraces, a sacred building, converging structure and form the higher the smaller. The arrangement of the outer part of the pendhapa the joglo is covered with a roof that rises up in the shape of a like a mountain at the top connected to the longitudinal mala, ordinary people Java calls penuwun. In the middle joglo has a support structure at the top, the name is saka guru, in the form of wood material amounting to four with a square formation. Part under the teacher's saka is supported by an umpak or a rock made of stone. If you look closely, the structure and the shape of the joglo house is the same as the structure and the shape of a Hindu temple.Therefore, it can be guessed that the joglo house is a form of transformation temple shape. (GUtierez, 2004).

Traditional buildings or traditional houses areone form of culture that is concrete.In its construction, every part/space in a traditional house is full of values and normsthat applies to the community that owns the culture Likewise with joglo, construction a distinctive building with the function of every part that are different from each other contain elements philosophically loaded with religious values, beliefs, norms, and cultural values of ethnic customs Java. In addition, joglo also has meaning history that needs to be preserved and preserved. Javanese traditional house can still be found at the Surakarta Palace and the Yogyakarta Palace tropical in character as an effort to adapt to the tropical environmental conditions. One form of adjustment to conditions that is by making a front porch wide area, protected from the hot sun by wide hanging roof, expanding all overangle on the roof of the joglo. Javanese traditional house which have various forms, have a typical division of space, which consists of pendhapa, pringgitan, and dalem. There is an application of the principle of hierarchy in the pattern spatial arrangement. Each room has difference in value, the front room isgeneral (public), and the back is special (private/private). 
Uniquely, every room from the terrace, pendhapa to the back (pawon and pekiwan) not only has a function but is also loaded with elements Javanese ethnic philosophy of life. Elements of religion/belief against gods manifested by space worship of Dewi Sri (Goddess of fertility and household happiness) according to Javanese people's livelihood (petaniagraris).

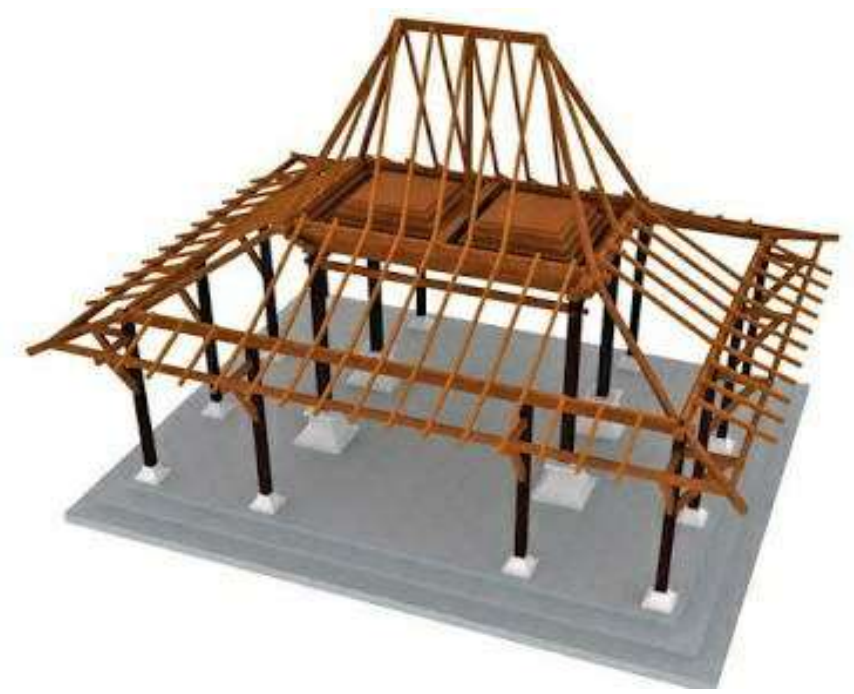

Figure 1. Joglo Construction Building

\subsection{Local Wisdom of Java Herritage}

Cosmology is a concept that was known to the Javanese before the arrival of the influence of Hinduism. However, with the arrival of Indian Hindu influence, the concept has nuances the outside is getting perfected even though the contents are the same, or like changing new clothes even though the body is still the old one. Therefore, the house for the Javanese is not enough just as a place to live. The house is a symbolic unit for the owner so that the position of the house is a reflection of the personality and life of its inhabitants. Thus, analyzing traditional Javanese houses is the same as discussing Javanese people and their culture as a whole.

The vertical structure of the house consists of three levels. At the top is called the head, the middle is called the body, while the bottom is likened to the feet. The Javanese house is an imitation of a mountain whose peak towers upward. Meru is the name of the mountain that is believed to be the place where the gods reside. Generally, traditional houses are shaped like Meru. It's not strange if in kejawen mysticism, the mountains that Meru imagined were realized in the form of mountains wayang kulit purwa which is known as kaju which means tree of life.

As an illustration, it can be shown when the puppeteer purwa sticks a gunungan in the right position in the middle of the screen before the puppet show begins. The Gunungan or kayon illustrates the Javanese mind that in the beginning there was no birth, still awang-uwung, the first was only kaju. Soon after that the mountain was pulled down by the dalang, symbolizing the existence of the first substance incarnation (gesang heelis). In fact, then what's interesting is that the mountain is pulled down stops three times. It could be that it is a symbol of the three opening levels of the maligai system which is located in the head as a source of creativity or a prosperous baital. The second level of its place on the chest is a source of flavor which in the wirid hidayat teak fiber is called baital-mukaram. 
The third level is at the bottom, where the genitals, this place is the source of the karsa or baital mukadas. The mountain then moved, moving so that it was no longer in the middle. This implies a deep meaning after the movement of the kayon (mountain) in the middle of the screen, indicating that there is life or kaju, namely the baby will be born.

Kayon or gunungan, whose essence is the embodiment of a traditional Javanese house, is a symbol of life or life Therefore, the house in the Javanese view of life is believed to be the link between the earth (the underworld) and the sky (the world above). That height structure becomes the medium and the axis mundi which connects the immanent human world with the supernatural world which is transcendent.

Communication is the process of delivering messages by someone to other people to tell, change attitudes, opinions or behavior either directly orally or indirectly through the media. In this communication requires a reciprocal relationship between the delivery of messages and recipients namely communicators and communicants (Hasbullah, et al: 2018).

The apex of the structure of the house is the place where the metacosm exists, the spiritual world which is unseen and invisible. At the top of the roof top there is only a cloud of uwung which in outward view of this phenomenon describes a single, empty universe, but inwardly the nature does not only mean empty but at the same time contains everything. This is the view of the Javanese in interpreting the house as a medium of communication to the paradoxical-empty, namely the One who is both there is and is not. The Being is beyond the reach of human experience in this world. He is not empty but at the same time everything that is and that may be, is empty but the full content of man, the world and the universe comes from there.

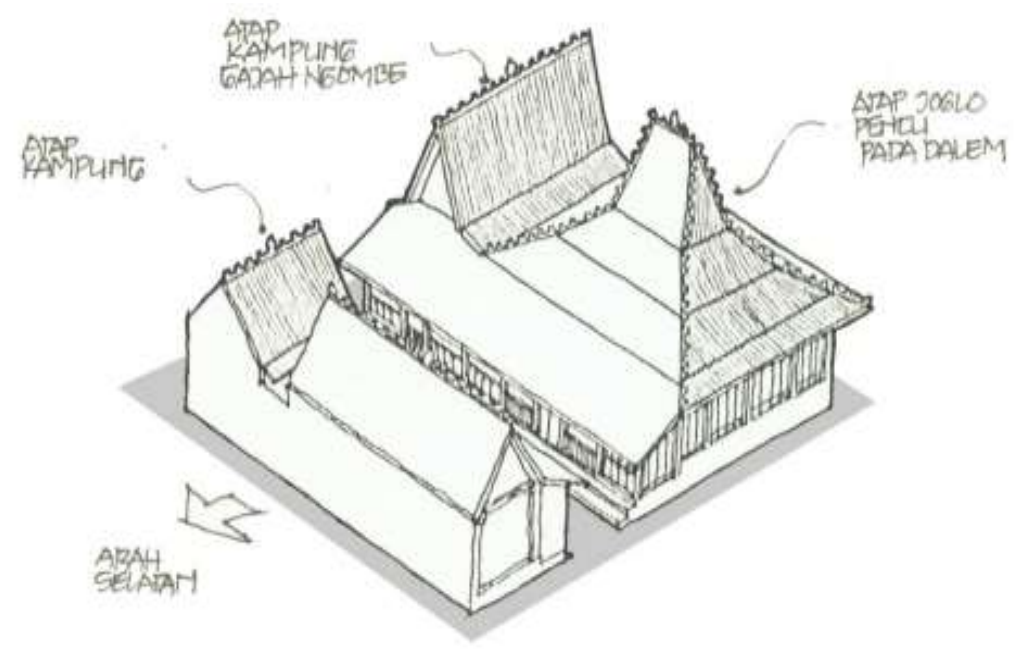

Figure 2. Local Wisdom Building of Joglo House 


\section{Conclusion}

The values of local wisdom are not obsolete values that must be turned off, but can synergize with universal values and modern values brought about by globalization. International world very demanding democracy, human rights, the environment into the development agenda in every country. These issues can synergize with the actualization of Hamemayu Hayuning Bawana's philosophy, the community must behave and behave that always prioritizes harmony, harmony, harmony and balance in the relationship between humans and nature, humans and humans and humans and Go in carrying out life and life so that the country becomes a nation. Hamemayu Hayuning Bawana can be realized with Hamemasuh Pemaning Bumi, which is cleaning or securing actions that violate human rights.

The destruction of the Earth can be in the form of war, ethnic eradication, drug abuse, use of weapons of mass destruction, terrorism, disease outbreaks, forest fires, and others that endanger human life and the natural environment. Western ratios and creativity can synergize with Hangengasah Mingising Budi, who describes continuous efforts to sharpen the mind/humans so that they become sharper from time to time.

\section{References}

Ahimsa-Putra, H.S. 2008. Ilmuwan Budaya dan Revitalisasi Kearifan Lokal: Tantangan Teoritis dan Metodologis.Disampaikan pada Rapat Senat Terbuka Dies Natalis ke-62 Fakultas Ilmu Budaya UGM Yogyakarta 3 Maret 2008.

Ambrose, James \& Vergum, Dimitry. 1999. Design for Earthquakes. New York: John Wiley \& Sons, Inc.

Arif, S. (2019). Influence of Leadership, Organizational Culture, Work Motivation, and Job Satisfaction of Performance Principles of Senior High School in Medan City. Budapest International Research and Critics Institute-Journal (BIRCI-Journal). P. 239-254

Arya Ronald, Nilai-Nilai Arsitektur Rumah Tradisional Jawa, Yogyakarta: UGM University Press, 2005.

Boen, Teddy et al. 1995. Manual Perbaikan dan Perkuatan Bangunan yang Rusak Akibat Gempa Bumi. Jakarta: Teddy Boen \& Rekan.

Boen, Teddy. 1978. Manual Bangunan Tahan Gempa (Rumah Tinggal). Jakarta: Teddy Boen \& Rekan.

Brush, Stephen B. \& Stabinsky, Doreen. 1996. Valuing Local Knowledge: Indigenous People and Intellectual Property Rights. USA: Island Press.

Ellen, Roy; Parkes, Peter; \& Bicker, Alan. 2005. Indigenous Environmental Knowledge and Its Transformations. Amsterdam: Harwood Academic Publisher.

Gutierrez, Jorge. 2004. "Notes on the Seismic Adequacy of Vernacular Buildings". 13th World Conference on Earthquake Engineering.

Hasbullah, Hatta, M., and Arifin, Z. (2018). Communication Pattern of Wilayatul Hisbah, Lhokseumawe City in Implementing Amar Makruf Nahi Mungkar. Budapest International Research and Critics Institure Journal, Vol. 1, No. 4, 194-205.

Masaeli, S. (2009). Plan acquired as a religious belief in traditional housing Iranian desert. Journal of Fine Arts, 37, 27-38.

Memarian, G. H. (1996). Housing pattern in traditional architecture with introspective approach. Tehran: Elmosanat University.

Naghizade, M. (2000). Qualitative characteristics of good housing design principles and methods of its study. Soffeh Journal, 10(31), 90-103.

Niati, D. R., Siregar, Z. M. E., \& Prayoga, Y. (2021). The Effect of Training on Work Performance and Career Development: The Role of Motivation as Intervening Variable. Budapest International Research and Critics Institute (BIRCI-Journal): Humanities and Social 
Sciences, 4(2), 2385-2393. https://doi.org/10.33258/birci.v4i2.1940

Pandapotan, S. (2020). Descriptive Study: Cross-Nation Marriage Family between Foreign Citizen and Local Citizen in Timbang Jaya Village, Bahorok Sub-District, Langkat Regency. Budapest International Research and Critics Institute-Journal (BIRCI-Journal) Volume 3, No 2, Page: $1499-1505$.

Pourdeyhimi, Sh. (2010). Culture and Housing. Journal of Housing and Rural Environment, 30(134), 3-18.

Triyadi, Sugeng, Harapan, Andi, Pribadi, Krishna S., Hidayat, B. 2009. Indigenous Knowledge on House Building System in West Sumatra and Southern-West Java, Indonesia. Text Book Indigenous Knowledge and Disaster Risk Reduction, From Policy to Practice, Editor : Rajib Shaw, Anshu Sharma, Yukiko Takeuchi. USA: NOVA Publisher. 